\title{
Mechanism of curcumin resistance to human cytomegalovirus in HELF cells
}

\author{
Yali Lv, Zhuoling An, Hui Chen, Zihui Wang and Lihong Liu*
}

\begin{abstract}
Background: We have previously shown that curcumin exhibited an outstanding anti-HCMV effect in vitro and in vivo. However, the underlying mechanism for the anti-HCMV effect remains unclear.

Methods: Levels of IL-6 and TNF-a cytokine secretions in HELF cells were determined by enzyme-linked immunosorbent assay (ELISA); cell cycles were assessed by flow cytometry; ie and ul83 gene expressions were evaluated using reverse transcriptase real-time quantitative PCR; HCMV IE and UL83 antigen expressions were studied using immunofluorescence staining assay and western blot.

Results: Curcumin reduced HCMV immediate early antigen (IEA) and UL83A expressions and IL-6, and TNF-a secretions and recovered cell proliferation to normal level in HCMV infected HELF cells.

Conclusions: Curcumin anti-HCMV effect may possibly be that curcumin concurrently alters host cell microenviroment and inhibits the HCMV antigen expressions. These findings may provide a basic understanding of the curcumin anti-HCMV effect and a novel strategy for further development of curcumin anti-HCMV treatment.
\end{abstract}

Keywords: Human cytomegalovirus, Curcumin, Cytokine secretion, Cells cycle, Gene expression, Immediate early antigen, IEA, UL83A

\section{Background}

Human Cytomegalovirus (HCMV) infects $50-90 \%$ of the general adult population and has been implicated in development of many diseases [1-3]. Although HCMV infects a wide spectrum of cell types in vivo, most laboratory studies are carried out using fibroblasts because the virus replicates relatively poorly in other cultured cells. The course of HCMV infection in human fibroblasts involves (i) direct fusion with the plasma membrane, (ii) entry and delivery of capsids into the cytoplasm [4], (iii) leaving viral DNA into the nucleus, and (iv) performing gene expression. Lytic gene expression follows a regulated cascade through three distinct phases: immediate-early (IE), early (E), and late (L), and finally, to release infectious virions. HCMV is known to highjack the host replication machinery, alter the cell cycle, and manipulate the host innate and adaptive immune responses [5]. IE72 and IE86, the most abundant immediate-early antigens (IEA) of HCMV, not only transactivate their own gene promoters

\footnotetext{
* Correspondence: hongllh@126.com

Department of pharmaceutical affairs, Beijing Chao-Yang Hospital, Capital Medical University, No. 8 GongrenTiyuchangNanlu, Chaoyang District, 100020 Beijing, P. R. China
}

and subsequent other viral gene promoters but also regulate the host cell cycle related gene expressions by interacting with cellular proteins to create a beneficial cellular microenvironment for viral proliferation [6,7]. Early antigen (EA) is a series of enzymes, such as UL54 and regulatory factors that are necessary to synthesis of progeny viral DNAs and proteins. Late antigens (LA) are the virus structural proteins, among which include UL83 and pp65 [8]. During the infection, HCMV enhances expression of several cytokines, such as tumor necrosis factor-alpha (TNF- $\alpha$ ) and interleukin-6 (IL-6), for the viral replication and dissemination [9], and inhibition and blocking of normal cell cycle progression prior to $S$ phase to provide a favorable environment for viral replication $[10,11]$.Thus, HCMV may manipulate the host environment to establish productive infection and ensure progression of the viral replication cycle, which may cause serious life threatening complications in immunocompromised individuals.

Treatment of HCMV infections is difficult because there are only a few options. To date, most of the licensed drugs such as ganciclovir (GCV), valganciclovir, and cidofovir 
that target the viral DNA polymerase [12], possess many drawbacks, including long-term toxicity, low potency, and poor bioavailability. In addition, the emergence of drugresistant viral strains of HCMV has become an increasing problem for the management of diseases caused by the virus. Our previous work showed that curcumin, a hydrophobic polyphenol and a natural compound that is derived from the rhizome of the herb Curcuma longa [13], exhibited an outstanding anti-HCMV activity in vitro $[14,15]$. Due to a wide spectrum of biological and pharmacological activities, curcumin is affirmed and promoted by biological medicine. Recently, it was found that curcumin can effectively protect against the potentially fatal Rift Valley fever (RVF) virus infection in vitro and in vivo [16]. Currently, studies are in progress to evaluate the activity of curcumin against the Bunyavirus, Venezuelan equine encephalitis virus and retrovirus, including human immunodeficiency virus (HIV). Therefore, curcumin may be used as a broad-spectrum inhibitor to prevent a series of virus infection in healthy cells.

However, there has been no study on the mechanism of the curcumin anti-HCMV effect. The purpose of this study was to investigate the mechanism of the curcumin anti-HCMV effect. We found that curcumin had different action mechanism than that of the polymerase targeting anti-HCMV drugs. Curcumin likely prevented HCMV from altering host cell microenviroment and HCMV antigen expressions. These findings may provide a novel anti-HCMV treatment strategy.

\section{Methods}

\section{Reagents and kits}

Dulbecco's Modified Eagle's Medium (DMEM), fetal bovine serum (FBS), SYBR Green, penicillin, streptomycin, L-glutamine, trypsase, dimethlsulfoxide (DMSO), Triton $\mathrm{X}-100$, phenylmethanesulfonyl fluoride (PMSF), â-mercaptoethanol (â-ME), TNF- $\alpha$ detection kit, IL-6 ELISA kit, and cell cycle assay kit were obtained from SigmaAldrich (St. Louis, MO, USA). Mouse anti-HCMV IE and mouse anti-HCMV UL83 were purchased from Abcam, USA. Secondary antibody goat anti-mouse and Platinum ${ }^{\circ}$ Quantitative PCR SuperMix-UDG were obtained from Invitrogen, USA. RNeasy Mini Kit and Sensiscript Reverse Transcriptase Kit were purchased from Qiagen (Valencia, CA, USA).

\section{Cell culture and virus propagation}

Human embryonic lung fibroblast (HELF) cells were purchased from National Platform of Experimental Cell Resources for Sci-Tech (Beijing, China) and cultured in DMEM supplemented with 10\% FBS, $100 \mathrm{U}$ of penicillin/ $\mathrm{ml}, 100 \mathrm{ig} / \mathrm{ml}$ of streptomycin, and $2 \mathrm{mML}$-glutamine at $37^{\circ} \mathrm{C}$ under a humidified condition of $95 \%$ air and $5 \%$ $\mathrm{CO}_{2}$. HCMV laboratory strain AD169 was purchased from ATCC, prepared in HELF cells and maintained in DMEM with $2 \%$ FBS (maintenance medium). The maximal atoxic concentration $\left(\mathrm{TC}_{0}\right)$ and half maximal inhibitory concentration $\left(\mathrm{IC}_{50}\right)$ of curcumin cytotoxicity and GCV and viral titer were determined by plaque titration as described previously $[13,14]$.

\section{Antiviral compounds}

Curcumin was obtained from National Institute for Food and Drug Control (Beijing, China) and stored as $50 \mathrm{mM}$ stock solution in DMSO for in vitro use. The high dose, middle dose, and low dose of curcumin were 0.8, 0.4, and $0.2 \mathrm{ig} / \mathrm{ml}$, respectively. The intravenous formulation of GCV (Sigma-Aldrich, St. Louis, MO, USA) at $50 \mathrm{ig} / \mathrm{ml}$ in $0.9 \%$ saline was used as reference.

\section{Enzyme-linked immunoabsorbent assay (ELISA)}

HELF cells that were seeded at density of $1 \times 10^{6} / \mathrm{ml}$ in tissue culture flasks were infected with HCMV at $100 \mathrm{TCID}_{50} / 0.1 \mathrm{ml}$. After incubation at $37^{\circ} \mathrm{C}$ for $2 \mathrm{~h}$ under a humidified condition of $95 \%$ air and $5 \% \mathrm{CO}_{2}$, the supernatant was removed and replaced by the maintenance medium with or without curicumin. After 48 hours, the supernatants were harvested and the levels of inflammatory cytokines IL- 6 and TNF- $\alpha$ were detected.

\section{Flow cytometry}

HELF cells that were seeded at density $1 \times 10^{6} / \mathrm{ml}$ in tissue culture flasks were synchronously cultivated for $12 \mathrm{~h}$, and then infected with $\mathrm{HCMV}$ at $100 \mathrm{TCID}_{50} / 0.1 \mathrm{ml}$. After incubation at $37^{\circ} \mathrm{C}$ for $2 \mathrm{~h}$ under a humidified condition of $95 \%$ air and $5 \% \mathrm{CO}_{2}$, the supernatant was removed and replaced by the maintenance medium with or without curcumin. After $48 \mathrm{~h}$, the cells were harvested, centrifuged at $800 \mathrm{~g}$ for $5 \mathrm{~min}$, washed with cold PBS two times, centrifuged at $800 \mathrm{~g}$ for $5 \mathrm{~min}$, and re-suspended with $70 \%$ ethanol at $4{ }^{\circ} \mathrm{C}$ overnight. The cells were centrifuged at $800 \mathrm{~g}$ for $5 \mathrm{~min}$, washed with PBS three times and incubated with $500 \mathrm{il} \mathrm{of} \mathrm{PBS} \mathrm{containing} 50 \mathrm{ig} / \mathrm{ml}$ propidium iodide (PI), $100 \mathrm{ig} / \mathrm{ml}$ RNase $\mathrm{A}$ and $0.2 \%$ Triton $\mathrm{X}-100$ at $4^{\circ} \mathrm{Cin}$ a dark cabinetfor $30 \mathrm{~min}$.

\section{SYBR green reverse transcriptase real-time quantitative PCR}

Total RNAs were extracted from cells and treated with Dnaseusing a QiagenRNeasy kit according to the manufacturer's instructions. RNA (500 ng) was subjected to reverse transcription. Each reaction mixture contained a cDNA template, $10 \mu \mathrm{M}$ of forward primer and reverse primer [17,18] (Oligonucleotide primers (Beijing DingguoChangsheng Biotechnology CO., Ltd, Beijing, China) are as follows: IE forward 5'-AGACACCCGTG ACCAAG-3', IE reverse 5' -TCTGTTTGACGAGTTCTG C-3'; UL83 forward 5'-ATGGTGGCTACGGTTCA -3', 
UL83 reverse 5'-CCTCGGTGCTTTTTGG-3'; GAPDH forward 5'-AGACACCCGT GACCAAG-3', GAPDH reverse 5'-TTTGAGGGTGCAGCGAACTT-3'), $2 \times$ Mix, $10 \times$ Sybr Green I and $\mathrm{dH}_{2} \mathrm{O}$. Amplification was performed by a cycle of initial denaturation at $94^{\circ} \mathrm{C}$ for $2 \mathrm{~min} ; 40$ cycle of denaturation at $94^{\circ} \mathrm{C}$ for $30 \mathrm{~s}$, annealing at $61^{\circ} \mathrm{C}$ for $30 \mathrm{~s}$, and elongation at $72^{\circ} \mathrm{C}$ for $30 \mathrm{~s}$. The fluorescence threshold value was calculated using $\mathrm{ABI} 7700$ device system software (Applied Biosystems Inc., Foster City, CA, USA). The calculation of relative change in mRNA was performed using the delta-delta method [19], with normalization to GAPDH.

\section{Immunofluorescence assay}

Cells that were seeded on non-coated glass coverslips at a density of $1 \times 10^{6} / \mathrm{ml}$ were washed with PBS three times and fixed with $4 \%$ paraformaldehyde at room temperature (RT) for 15 min. Cells were washed with PBS three times, each time $5 \mathrm{~min}$, followed by permeablization in $0.5 \%$ Triton X-100/PBS for $8 \mathrm{~min}$. The cells were washed with PBS and blocked in blocking buffer (10\% goat serum in $\mathrm{PBS}$ ) at $37^{\circ} \mathrm{C}$ for $1 \mathrm{~h}$. After blocking, the cells were incubated with primary mouse monoclonal antihuman IE and UL83 antibodies in a moist chamber at $37^{\circ} \mathrm{C}$ for $1 \mathrm{~h}$. Then the cells were rinsed with PBS and incubated with secondary goat anti-mouse fluoresceinconjugated antibody at $37^{\circ} \mathrm{C}$ for $1 \mathrm{~h}$ in a dark cabinet, followed by successive washes with PBS and imaged at 200x using an Olympus microscope (Olympus IX71, Japan). The acquired images were processed using Adobe Photoshop software.

\section{Western blotting}

The cells were washed with cold PBS twice and lysed in an appropriate volume of cold RIPA buffer [25 mM Tris- $\mathrm{HCl}$ pH 7.6, 150 mM NaCL, 1\% NP-40, 1\% sodium deoxycholate, $1 \mathrm{mM}$ PMSF and $0.1 \%$ sodium-dodecyl sulphate (SDS)] on ice for $30 \mathrm{~min}$; then they were crushed at $4^{\circ} \mathrm{C}$ and centrifuged at $9600 \mathrm{~g}$ for $10 \mathrm{~min}$. The supernatant was removed and denatured by heating at $95^{\circ} \mathrm{C}$ for $10 \mathrm{~min}$. Proteins were separated by SDS-PAGE
(Mini-Protean ${ }^{\oplus}$ Tetra System, Bio-RAD, Hercules, CA, USA), electroblotted onto nitrocellulose membranes (Mini-Trans-Blot, Bio-RAD, Hercules, CA, USA). After being blocked with $5 \%$ skim milk in Tris-buffered saline (TBS) consisting of $100 \mathrm{mmol} / \mathrm{L}$ Tris $\cdot \mathrm{HCL}, 150 \mathrm{mmol} / \mathrm{L}$ $\mathrm{NaCL}, \mathrm{pH} 7.4$ at room temperature for $2 \mathrm{~h}$, the blots were incubated with primary antibodies at the recommended dilutions at $4^{\circ} \mathrm{C}$ overnight, followed by washing with $0.05 \%$ Tween-20 in TBS (TBST) three times. Then the blots were then incubated with Alexa Fluor 680 goat antimouse IgG and goat anti-rabbit IgG at 1:10000 (Invitrogen, Grand Island, NY, USA) in TBST. After washing the membranes with TBS, signals were detected using Odyssey infrared laser imaging system (Li-COR, American) according to the manufacturer's instructions. For densitometric analysis of western blot images, density profiles of the bands were measured using ImageJ software.

\section{Statistical analysis}

Data were analyzed using Microsoft Office Excel 2003 and expressed as mean \pm standard error (SE). Group comparisons were evaluated using the one-way ANOVA, and significant differences between treatments were determined using the post hoc test with Tukey-Kramer HSD simultaneous pair wise main comparison. $\mathrm{P}$ values less than 0.05 were considered to be statistically significant.

\section{Results}

\section{Effect of curcumin on HCMV-induced cytokine secretion in HELF cells}

After incubation of HELF cells with HCMV for $48 \mathrm{~h}$, the concentrations of IL- 6 and TNF- $\alpha$ in model cells (cells only infected with $\mathrm{HCMV}$ ) were $431.46 \pm 21.3$ (Figure 1A) and $13.67 \pm 1.02 \mathrm{pg} / \mathrm{mL}$ (Figure $1 \mathrm{~B}$ ), respectively, which were markedly increased compared to the control (Figure $1 \mathrm{~A} ; P<0.01$ ). In contrast, the concentrations of IL- 6 and TNF- $\alpha$ in curcumin treated groups were slightly higher than basal levels, and significantly different from model cells (Figure 1D-F; $P<0.05$ ).

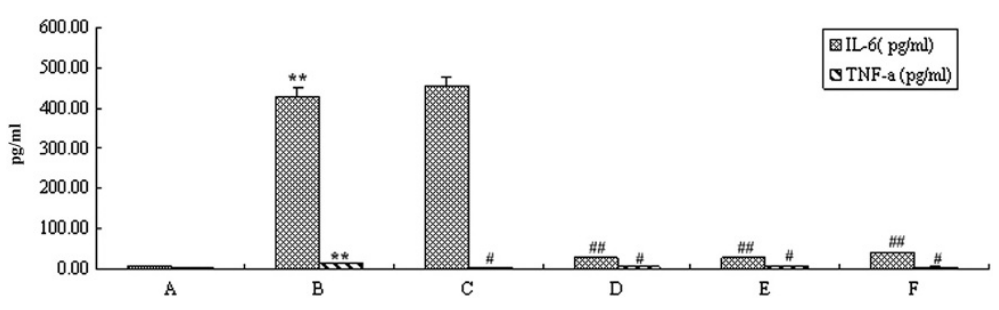

Figure 1 Effect of curcumin on IL-6 and TNF-a secretions in HCMV infected HELF cells. A, HELF cells (control); B, HELF cells + HCMV (model); C, HELF cells + HCMV + GCV; D, HELF cells + HCMV + curcumin (high dose: $0.8 \mu \mathrm{g} / \mathrm{ml}$ ); E, HELF cells + HCMV + curcumin (Middle dose: $0.4 \mathrm{ig} / \mathrm{ml}) ; \mathbf{F}$, HELF cells + HCMV + curcumin (low dose: $0.2 \mathrm{ig} / \mathrm{ml}$ ). ${ }^{* *} P<0.01,{ }^{*} P<0.05$ compared with the control; ${ }^{\# \#} P<0.01,{ }^{\#} P<0.05$ compared with HCMV infection. 
Effect of curcumin on the cell cycle infected by HCMV

The effect of curcumin on the HELF cell cycle infected by HCMV was investigated using flow cytometry. After incubation of HELF cells with HCMV for $48 \mathrm{~h}$, the S phase fraction in model cells (Figure $2 \mathrm{~B}$ ) was significantly greater than in the control cells (Figure 2A; $P<0.05$ ), while $G_{0} / G_{1}$ and $G_{2} / M$ phase fraction in model cells were less than in the control cells (Figure 2A-B; $P<0.05$ ), which indicated that HCMV inhibited cell proliferation. Compared to model cells, cell proliferation of curcumin treated groups (Figure 2D-F) basically returned to normal levels (Figure 2D-F; $P<0.05$ ).

\section{Down-regulation of the gene expression of $\mathrm{HCMV}$ ie and ul 83 by curcumin}

To further explore the mode of action of curcumin, we evaluated the effect of curcumin on HCMV IE and UL83 mRNA expressions using real-time quantitative PCR (Figure 3). At the indicated time points ( $48 \mathrm{~h}$ post infection), there were no HCMV IE or UL83 mRNA expression (Figure $3 \mathrm{~A}$ ) in mock cells. In contrast, there were significant HCMV IE and UL83 mRNA expressions (Figure 3B) found in cells infected by HCMV $(P<0.01)$. A distinct reduction of IE and UL83 mRNA expressionswere observed in cells treated with curcumin (Figure 3D-F; $P<0.01)$.

\section{Modulation of HCMV IE antigen (IEA) and UL83 antigen (UL83A) levels by curcumin}

We next determined if the transcriptional changes by curcumin also affected HCMV IEA and UL83A levels in the cells at $48 \mathrm{~h}$ post infection. HCMV infection increased the levels of IEA and UL83A expressions (Figures 4B and $5 \mathrm{~B}$ ) compared to the mock-infected cells (Figures 4A and 5A; $P<0.01$ ). However, HCMV IEA and UL83A expressions were obviously down-regulated in the cells treated with curcumin (Figure 4D-F and 5D-F; $P<0.05$ ).

\section{Discussion}

To address the mechanism of curcumin in the anti-HCMV effect, we investigated the proliferation, HCMV IEA and

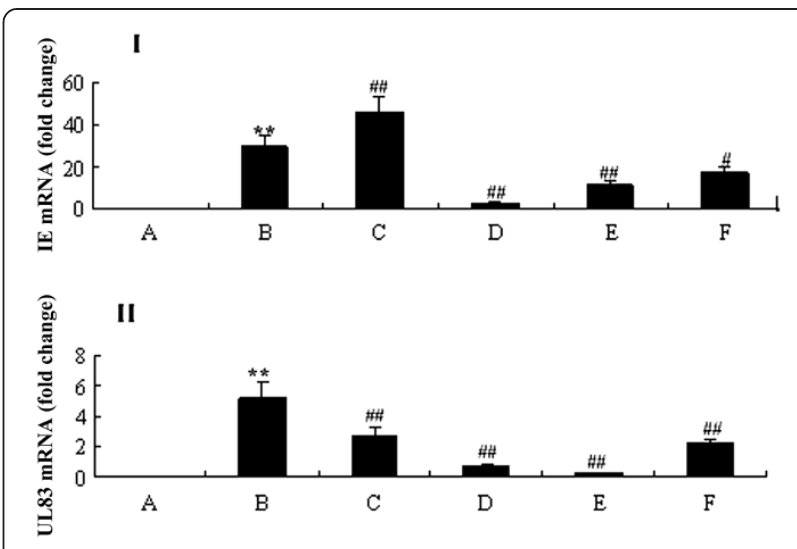

Figure 3 Effect of curcumin on HCMV IE and UL83 expressions. (I) Relative HCMV IE mRNA expression was normalized to GAPDH mRNA levels and expressed as fold change. (II) Relative HCMV UL83 mRNA expression was normalized to GAPDH mRNA levels and expressed as fold change. A, HELF cells (control); B, HELF cells + HCMV (model); $\mathbf{C}$, HELF cells + HCMV + GCV; $\mathbf{D}$, HELF cells + HCMV + curcumin (high dose: $0.8 \mu \mathrm{g} / \mathrm{ml}$ ); E, HELF cells + HCMV + curcumin (middle dose: $0.4 \mu \mathrm{g} / \mathrm{ml}$ ); F, HELF cells + HCMV + curcumin (low dose: $0.2 \mu \mathrm{g} / \mathrm{ml}$ ).

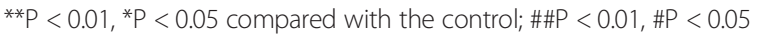
compared with HCMV infection.

UL83A expressions, IL-6 and TNF- $\alpha$ secretions and ieand ul83 gene expressions of HELF cells treated by curcumin using flow cytometry, western blotting/immunofluorescence assay, ELISA and RT qPCR, respectively. We identified that curcumin concurrently altered the host cells microenviroment and inhibited the HCMV antigen expressions in HCMV infected HELF cells. We found that IL- 6 and TNF- $\alpha$ levels in the cells infected with HCMV were significantly higher than in the mock infected cells, but curcumin significantly reduced the secretion of the two cytokines, suggesting that curcumin may be an effective anti-HCMV infection agent. TNF- $\alpha$ may promote HCMV replication that may in turn increase the TNF- $\alpha$ secretion level. In fact, IL- 6 and TNF- $\alpha$ levels in HCMV infected patients'sera are significantly higher, and the high level of IL-6 may indicate a higher risk of HCMV infection, thus being beneficial for early diagnose of HCMV infection [20,21].

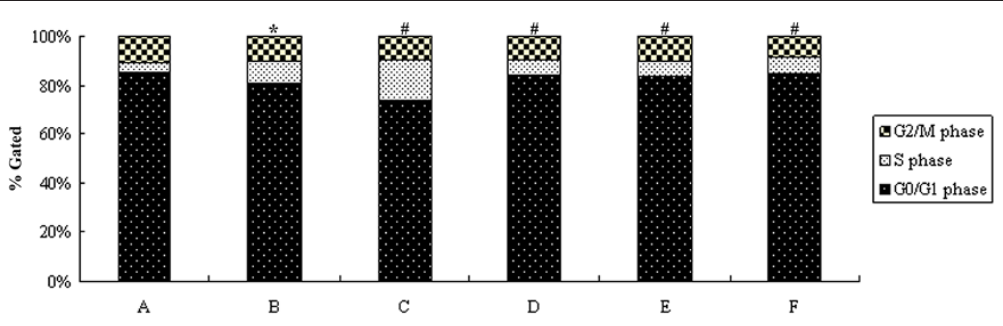

Figure 2 Effect of curcumin on HCMV infected HELF cell cycle. A, HELF cells (control); B, HELF cells + HCMV (model); C, HELF cells + HCMV + GCV; D, HELF cells + HCMV + curcumin (high dose: $0.8 \mu \mathrm{g} / \mathrm{ml}$ ); E, HELF cells + HCMV + curcumin (middle dose: $0.4 \mu \mathrm{g} / \mathrm{ml}$ ); F, HELF cells + HCMV + curcumin (low dose: $0.2 \mu \mathrm{g} / \mathrm{ml}$ ). ${ }^{*} P<0.05$ compared with the control; ${ }^{\#} P<0.05$ compared with HCMV infection. 


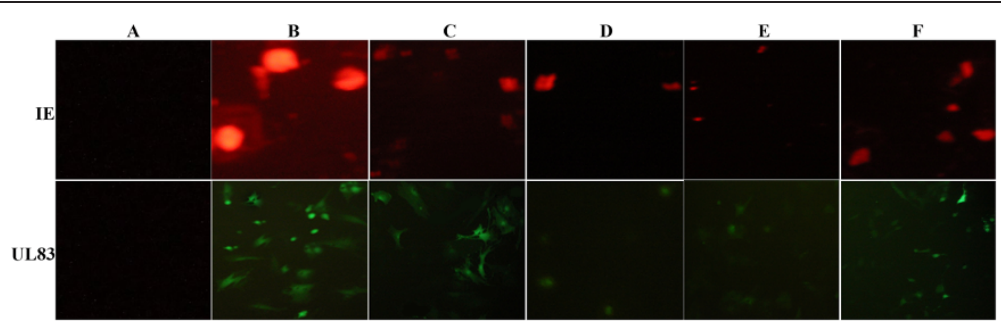

Figure 4 Effect of curcumin on HCMV IE and UL83 protein expressions (200X). A, HELF cells (control); B, HELF cells + HCMV (model); C, HELF cells + HCMV + GCV; D, HELF cells + HCMV + curcumin (high dose: $0.8 \mu \mathrm{g} / \mathrm{ml}$ ); E, HELF cells + HCMV + curcumin (middle dose: $0.4 \mu \mathrm{g} / \mathrm{ml}$ ); $\mathbf{F}$, HELF cells + HCMV + curcumin (low dose: $0.2 \mu \mathrm{g} / \mathrm{ml}$ ).

We found that the percentages of S phase of the HCMV infected cells were significantly higher, but the percentages of $G_{0} / G_{1}$ and $G_{2} / M$ phases were much lower in the HCMV infected cells than in the mock infected cells. The cell cycle of HCMV infected cells basically recovered to normal status after curcumin treatment. These results indicated that curcumin may improve the cell cycle of HCMV infected cells which in turn may further inhibit the proliferation and replication of the virus. It was found that after HCMV infection in S phase, the host cells cycle progress was stopped in S phase, followed by cell pathologic mitosis [22], and that HCMV infected cells stopped dividing after entering the $\mathrm{S}$ phase [23]. It's worth noting that the cell cycle changes caused by HCMV were related to alterations of cell cycle factors, including increasing of CyclinE transcription activity, activating cyclin-dependent kinases (Cdks) and reducing the abundance of Cdk inhibitors (CKIs) $[11,24,25]$. Therefore, whether curcumin alters these cell cycle factors to regulate the cells cycle of HCMV infected cells needs to be further investigated.

Our previous work showed that curcumin likely downregulated the expressions of HCMV IE and UL83 mRNAs by semi-quantitative PCR (data not shown), thereby we further studied the molecular mechanism of curcumin in

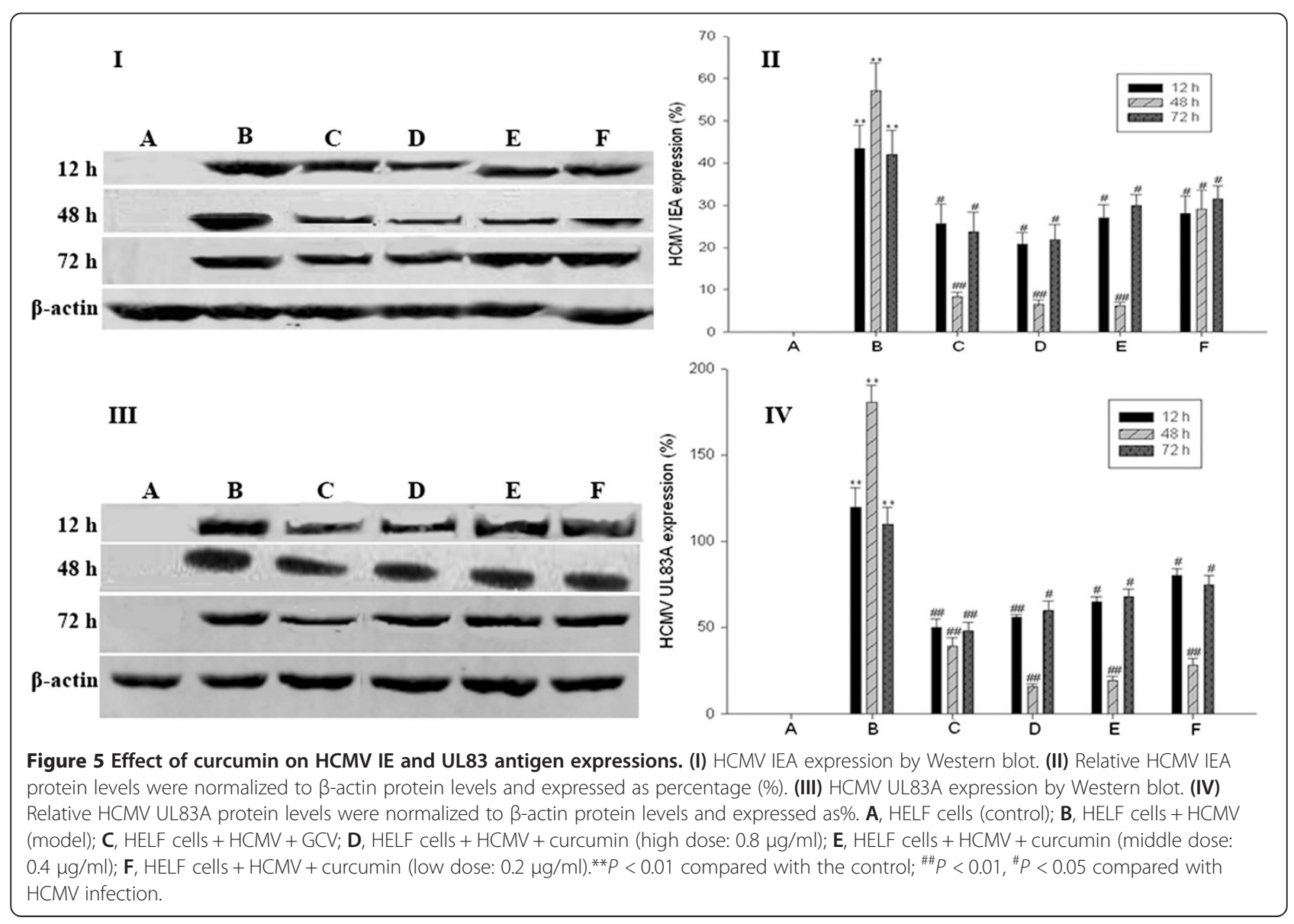


downregulating of HCMV antigen expressions. We found that curcumin significantly reduced HCMV IE and UL83 mRNA expressions and IEA and UL83 protein expressions. These findings suggest that the curcumin anti-HCMV effect may be through the inhibition of antigen IEA and UL83A expressions, which is different from the GCV anti-HCMV mechanism targeting viral DNA polymerase UL54 [12]. HCMV infection provokes a proinflammatory response characterized by an increased expression of chemokines, adhesion molecules, and modulation of angiogenesis, which in turn promotes progressive HCMV infection. IL-6 drives reactivation of latent HCMV infection by transcriptional upregulation of IE genes [26]; HCMV IE and late proteins play important roles in immune evasion such as TNF-mediated death receptor signaling pathway, TNF- $\alpha$ release, IL-6 production $[27,28]$. We deduce that curcuminreduces HCMV IE and UL83 expression, which in turn decreases inflammatory factor secretion and recovers host cell cycle to normal status. In fact, viral IE and UL83 expression play a key role in the pathogenesis of HCMV infection [29,30]. Yet a further study of the curcumin anti-HCMV infection mechanism is necessary.

\section{Conclusion}

We have identified that curcumin had a clear anti-HCMV effect and suggest that the underlying mechanism may be that curcumin alters the host cells microenviroment and inhibits the of HCMV protein expressions. These findings may present curcumin as a novel drug in anti-HCMV treatment with different mechanism of action from the existing polymerase targeting anti-HCMV drugs.

\footnotetext{
Abbreviations

HCMV: Human cytomegalovirus; IE: Immediate-early; E: Early; L: Late; IEA: Immediate-early antigens; EA: Early antigen; LA: Late antigens; TNF-a: Tumor necrosis factor-alpha; IL-6: Interleukin-6; GCV: Ganciclovir; RVF: Rift Valley fever; HIV: Human immunodeficiency virus; DMEM: Dulbecco's Modified Eagle's Medium; FBS: Fetal bovine serum; DMSO: Dimethlsulfoxide; PMSF: Phenylmethanesulfonyl fluoride; â-ME: â-mercaptoethanol; HELF: Human embryonic lung fibroblast; $\mathrm{TC}_{0}$ : The maximal atoxic concentration; $\mathrm{I}_{50}$ : Half maximal inhibitory concentration; ELISA: Enzyme-linked immunosorbent assay; PI: Propidium iodide; RT: Room temperature; Cdks: Cyclin-dependent kinases; CKIs: Cdk inhibitors.
}

\section{Competing interests}

The authors declare that they have no competing interests.

\section{Authors' contributions}

$Y L$ performed the molecular genetic studies, participated in the sequence alignment and drafted the manuscript. ZA performed the immunoassays and participated in the sequence alignment. HC participated in the design of the study and performed the statistical analysis. LL conceived of the study, and participated in its design and coordination and helped to draft the manuscript. All authors read and approved the final manuscript.

\section{Acknowledgements}

This study was financially supported by the Chinese Postdoctoral Science Foundation (No. 2012 T50881). We thank Medjaden Bioscience Limited for assisting in the preparation of this manuscript.
Received: 4 September 2013 Accepted: 30 July 2014

Published: 4 August 2014

\section{References}

1. Dowd JB, Aiello AE, Alley DE: Socioeconomic disparities in the seroprevalence of cytomegalovirus infection in the US population: NHANES III. Epidemiol Infect 2009, 137(1):58-65.

2. Fisher RA: Cytomegalovirus infection and disease in the new era of immuno suppression following solid organ transplantation. Transpl Infect Dis 2009, 11(3):195-202.

3. Cheng J, Ke Q, Jin Z, Wang H, Kocher O, Morgan JP, Zhang J, Crumpacker CS: Cytomegalovirus infection causes an increase of arterial blood pressure. PLoS Pathog 2009, 5(5):e1000427.

4. Vanarsdall AL, Wisner TW, Lei H, Kazlauskas A, Johnson DC: PDGF receptor-a does Not promote HCMV entry into epithelial and endothelial cells but increased quantities stimulate entry by an abnormal pathway. PLoS Pathog 2012, 8(9):e1002905.

5. Jackson SE, Mason GM, Wills MR: Human cytomegalovirus immunity and immune evasion. Virus Res 2011, 157(2):151-160.

6. Murphy E, Shenk T: Human cytomegalovirus genome. Curr Top Microbiol Immunol 2008, 325:1-19.

7. Bai Z, Li L, Wang B, Liu Z, Wang H, Yan Z, Qian D, Ding S, Song X: Effect of Inducible expressed human cytomegalovirus immediate early 86 protein on cell apoptosis. Biosci Biotechnol Biochem 2009, 73(6):1268-12673.

8. Cristea IM, Moorman NJ, Terhune SS, Cuevas CD, O'Keefe ES, Rout MP, Chait BT, Shenk T: Human cytomegalovirus pUL83 stimulates activity of the viral immediate-early promoter through its interaction with the cellular IFI16 protein. J Virol 2010, 84(15):7803-7814.

9. Zheng Q, Tao R, Gao H, Xu J, Shang S, Zhao N: HCMV-encoded UL128 enhances TNF- $a$ and IL- 6 expression and promotes PBMC prolifer- ation through the MAPK/ERK PathwayIn vitro. Viral Immunol 2012, 25(2):98-105.

10. Dittmer D, Mocarski ES: Human cytomegalovirus infection inhibits $\mathrm{G} 1 / \mathrm{S}$ transition. J Virol 1997, 71(2):1629-1634.

11. Murphy EA, Streblow DN, Nelson JA, Stinski MF: The human cytomegalovirus IE86 protein Can block cell cycle progression after inducing transition into the $S$ phase of permissive cells. J Virol 2000, 74(15):7018-7108.

12. Griffiths PD: The treatment of cytomegalovirus infection. J Antimicrob Chemother 2002, 49(2):243-253.

13. Wang D, Hu J, Lv L, Xia X, Liu J, Li X: Enhanced inhibitory effect of curcumin via reactive oxygen species generation in human nasopharyngeal carcinoma cells following purple-light irradiation. Oncol Lett 2013, 6(1):81-85.

14. Yali L, Anjie L, Chao L, Ning L, Cheng W, Lihong L: Activity of curcumin against human cytomegalovirus in vitro. African J Pharm Pharmaco 2012, 6(1):30-35.

15. Yali L, Yuanyuan L, Dan W, Ning L, Lihong L: Activity of curcumin against human cytomegalovirus in vitro. Trad Chin Drug Res Clin Pharmaco 2012, 23(5):531-534

16. Narayanan A, Kehn-Hall K, Senina S, Lundberg L, Van Duyne R, Guendel I, Das R, Baer A, Bethel L, Turell M, Hartman AL, Das B, Bailey C, Kashanchi F: Curcumin inhibits Rift Valley fever virus replication in human cells. J Biol Chem 2012, 287(40):33198-33214.

17. Machado AM, de Souza WM, de Pádua M, da Silva Rodrigues Machado AR, Figueiredo LT: Development of a one-step SYBR Green I real-time RT-PCR assay for the detection and quantitation of Araraquara and Rio Mamore hantavirus. Viruses 2013, 5(9):2272-2281.

18. Zhang N, Liu Z, Han Q, Qiu J, Chen J, Zhang G, Li Z, Lou S, Li N: Development of a one-step SYBR Green real-time RT-PCR for quantifying bovine viral diarrhea virus type-1 and its comparison with conventional RT-PCR. Virol J 2011, 8:374.

19. Pfaffl MW: A new mathematical model for relative quantification in real-time RT-PCR. Nucleic Acids Res 2011, 29(9):e45

20. Tornatore KM, Garey KW, Saigal N, Reed K, Murray B, Ingalls E, DiFrancesco R, Forrest A, Morse G, Venuto R: Ganciclovirpharmacokinetices and cytokine dynamics in renal transplant recipients with cytomegalovirus infection. Clin Transplant 2001, 15(5):297-308.

21. Tong CY, Bakran A, Willams H, Cuevas LE, Peiris JS, Hart CA: As sociation of tumor necrosis factor alpha and interleukin-6 levels with cytomegalovirus DNA detection and disease after renal transplantation. J Med Virol 2001, 64(1):29-34 
22. Barsukova AS, Fedorova NE, Medzhidova AA: Effect of cytomegalovirus on cell cycle progression and formation of pathological mitoses in cultured diploid fibroblases. Ontogenez 2001, 32(1):29.

23. Salvant BS, Fortunato EA, Spector DH: Cell cycle dysregulation by human cytomegalovirus: influence of the cell cycle phase at the time of infection and effects on cyclin transcription. J Virol 1998, 72(5):3729-3741.

24. Zydek M, Uecker R, Tavalai N, Stamminger T, Hagemeier C, Wiebusch L: General blockade of human cytomegalovirus immediate-early mRNA expression in the S/G2 phase by a nuclear, Daxx- and PML-inde pendent mechanism. J Gen Virol 2011, 92(Pt12):2757-2769.

25. Zhenping C, Eugene K, Alexander K, Thomas A: Degradation of p21cip1 in cells productively infected with human cytomegalovirus. J Virol 2001, 75(8):3613-3625

26. Reeves MB, Compton T: Inhibition of inflammatory interleukin- 6 activity via extracellular signal-regulated kinase-mitogen-activated protein kinase signaling antagonizes human cytomegalovirus reactivation from dendritic cells. J Virol 2011, 85(23):12750-12758.

27. Taher C, de Boniface J, Mohammad AA, Religa P, Hartman J, Yaiw KC, Frisell J, Rahbar A, Söderberg-Naucler C: High prevalence of human cytomegalovirus proteins and nucleic acids in primary breast cancer and metastatic sentinel lymph nodes. PLoS One 2013, 8(2):e56795.

28. Rodríguez-Martín S, Kropp KA, Wilhelmi V, Lisnic VJ, Hsieh WY, Blanc M, Livingston A, Busche A, Tekotte H, Messerle M, Auer M, Fraser I, Jonjic S, Angulo A, Reddehase MJ, Ghazal P: Ablation of the regulatory IE1 protein of murine cytomegalovirus alters in vivo Pro-inflammatory TNF-alpha production during acute infection. PLoS One 2012, 8(8):e1002901.

29. Mercorelli B, Lembo D, Palù G, Loregian A: Early inhibitors of human cytomegalovirus: state-of-art and therapeutic perspectives. Pharmacol Ther 2011, 131(3):309-329.

30. Santo L, Marisa G, Giorgio G, David L: The human cytomegalovirus. Pharmacol Therapeut 2003, 98:269-297.

doi:10.1186/1472-6882-14-284

Cite this article as: Lv et al:: Mechanism of curcumin resistance to human cytomegalovirus in HELF cells. BMC Complementary and Alternative Medicine 2014 14:284.

\section{Submit your next manuscript to BioMed Central and take full advantage of:}

- Convenient online submission

- Thorough peer review

- No space constraints or color figure charges

- Immediate publication on acceptance

- Inclusion in PubMed, CAS, Scopus and Google Scholar

- Research which is freely available for redistribution 